\title{
ATTENTION DEFICIT HYPERACTIVITY DISORDER (ADHD) IN ADULTS
}

\section{Social-demographic profile from a university hospital ADHD outpatient unit in São Paulo, Brazil}

\author{
Maria Aparecida da Silva', Mário R. Louzã, Homero P. Vallada
}

\begin{abstract}
Purpose: To describe the social-demographic variables, including interpersonal, academic, and p rofessional perf o rmance in adult individuals with the diagnoses of attention deficit hyperactivity disor$\operatorname{der}(A D H D)$. There are no re $p$ orts of this kind in the Brazilian population with ADHD. The ADHD is a common disord e r, which can reach up to $3 \%$ of the general population. Method: Descriptive study of adults with ADHD, according to the DSM-IV criteria (American Psychiatric Association). The sample was selected f rom a specialized outpatient service in São Paulo city. The social-demographic data was obtained by personal interviews. Results: There was a predominance of males in the sample (61.2\%) and a high education level $(90.2 \%$ had at least a high school degree) and $52 \%$ of the 102 patients had repeated their class at a least once during their school lives. In addition, $22.5 \%$ of the population sample were unemployed at the time of the interview. Conclusion: The distribution of the socio-demographic variables in adult ADHD is similar to other ADHD samples reported in other countries, despite the high education level met in our sample. Similarities between child and adult ADHD could also be traced.
\end{abstract}

KEY WORDS: attention deficit hyperactivity disorder, adults, psychosocial impairment, outpatient service.

\begin{abstract}
Transtorno de déficit de atenção e hiperatividade (TDAH) no adulto: perfil sócio-demográfico de pacientes com TDAH atendidos em ambulatório de um hospital universitário de São Paulo, Brasil
\end{abstract}

RESUMO - Objetivo: Descrever as variáveis sócio-demográficas incluindo desempenho acadêmico, profissional e interpessoal em uma população adulta com diagnóstico de transtorno de déficit de atenção e hiperatividade (TDAH). Até o momento não há relato na literatura do perfil desses pacientes na população brasileira. O TDAH é comum na população geral, podendo chegar a $3 \%$ das pessoas. Método: Foram avaliados adultos que tomaram conhecimento do serviço de atendimento especializado em TDAH através da mídia. O diagnóstico de TDAH foi realizado utilizando-se os critérios da Associação Psiquiátrica Americana (DSM-IV). Os dados sócio-demográficos foram obtidos através de entrevista pessoal com cada paciente. Resultados: 102 indivíduos preencheram critérios para TDAH. Houve predomínio do sexo masculino $(61,2 \%)$ com alto nível de escolaridade $\left(90,2 \%\right.$ tinham no mínimo $2^{\circ}$ grau completo). Cinquenta e três pacientes $(52 \%)$ foram re p rovados pelo menos uma vez durante vida estudantil. No momento da entrevista, $22,5 \%$ encontravam-se desempregados. Conclusão: Observou-se uma semelhança da distribuição das variáveis sócio-demográficas com os indivíduos adultos com TDAH de outros países, apesar da escolaridade ser acima da média nacional. Além disso, pode-se também observar semelhanças entre as populações infantil e adulta com TDAH.

PALAVRAS-CHAVE: déficit de atenção e hiperatividade, adulto, prejuízo psicossocial, atendimento ambulatorial.

\footnotetext{
Department of Psychiatry, University of São Paulo, Faculty of Medicine, São Paulo SP, Brazil: ${ }^{1}$ Psychiatrist and Master in Science; ${ }^{2}$ Coordinator of the adult ADHD outpatient unit (PRODATH) at the Institute of Psychiatry; ${ }^{3}$ Head of the Genetics and Pharmacogenetics Programme (ProGene LIM-23) and Associate Professor at the Department of Psychiatry. This study received financial support from Fundação de Amparo a Pesquisa do Estado de Sao Paulo (FAPESP 03/13779-4) and from Conselho Nacional de Desenvolvimento Científico e Tecnológico (CNPq 306154/2004-8)
}

Received 25 October 2005, received in final form 28 March 2006. Accepted 27 April 2006.

Dr. Homero P. Vallada - Programa de Genética e Farmacogenética (ProGene LIM-23) - Instituto de Psiquiatria I HC-FMUSP - Rua Dr. Ovidio Pires de Campos 725 - 05403-010 São Paulo SP - Brasil. E-mail: montsil@uol.com.br 
Attention deficit hyperactivity disorder (ADHD) is one of the most common neuropsychiatric and behavioural disorders of childhood, and was first described in 1902 by the British physician George Still as a "defective moral control"1. Still proposed that this condition was based on a biological substrate that could be either hereditary and/or the result of some acquired encephalopathy, instead of, as it was believed at that time, the consequence of bad behavior or moral degeneration. Since then, this condition received several names: minimal brain damage, minimal brain dysfunction, hyperactive child syndrome and attention deficit disorder with or without hyperactivity ${ }^{2}$. These frequent changes reflect the uncertainty about the diagnose and etiology of this disorder. ADHD is characterized by a set of symptoms associated with the motor activity, impulsivity and attention, affecting 3\% to $6 \%$ of children with onset before 7 years ${ }^{3,4}$; the prevalence is 3-9 times higher in males ${ }^{5-7}$. It was believed that ADHD would disappear at the beginning of adult life, however studies carried out by Reimherr et al. ${ }^{8}$, observed that the symptoms of some child ren with this disorder persisted into adulthood. ADHD came to be largely reconceptualized as a lifespan disorder and not merely a condition of childhood. These researchers developed a clinical criteria for the diagnosis of adult ADHD (the Utah Criteria), which combined past history of ADHD with current evidence of present symptoms. Approximately $30 \%$ to $70 \%$ of these children maintain symptoms through adulthood serious enough to disrupt their daily lives ${ }^{9-}$ ${ }^{11}$. It is estimated that between $0.3 \%$ to $3 \%$ of the adult population ${ }^{12,13}$ are afflicted with ADHD and the p revalence in men is less dramatic, around $2: 1^{14}$. This difference in sex rate is probably because the disorder is less disruptive in women than in men in childhood, but in adulthood the impairments are similar.

Establishing the diagnosis in adults is particularly difficult, mainly of those that did not receive a diagnosis during childhood, since an overlap between the symptoms of adult ADHD and the symptoms of other frequent psychiatric conditions may occur. There are also difficulties in obtaining accurate information due to a bias in the recall of past informations $^{15}$. Reports from parents and other relatives are usually helpful. The symptoms of ADHD vary with age and development. The most important symptoms in adult patients are inattention, emotional lability, disorganized behavior, executive dysfunctions and disinhibition ${ }^{16}$. It is observed that hyperactivity decreases with age and inattention tends to persist ${ }^{17}$. In tedious situations or when poorly motivated, these patients complain about the difficulty in focusing attention and selecting relevant stimuli and consequently they are regarded as dreamy, distractible, oblivious and irresponsible ${ }^{16}$. Lack of persistence results in activities being constantly neglected; generally causing poor occupational and academic perf o rmance, resulting in dismissal from job that can also occur due to the difficulty in controlling the impulses, often leading to interpersonal conflicts in all areas ${ }^{18}$. Studies demonstrate that adults with ADHD have lower socioeconomic status, more difficulty at work and a greater number of job changes ${ }^{10,19,20}$. Furthermore, many of these patients are attracted to high risky activities, such as speeding, and are interested in radical sports which may offer a higher accident risk for those that try to satisfy their immediate needs. In conclusion, adult patients with ADHD suffer a significant impact during their lives, due to the functional losses in a variety of segments as affective, familiar, social, occupational, academic. Increased awareness of adult ADHD was initially spurred by non-specialized publications ${ }^{21}$. In Brazil, since 2000 , the media has been reporting this psychiatric condition, and this is helping people recognize some of the symptoms and look for help and further diagnosis.

There are sociodemographic descriptions of adult ADHD in different countries but none so far in Brazil. The present report describes the socio-demographic profile of adult ADHD patients treated in a specialized outpatient clinic from the University Hospital in São Paulo.

\section{METHOD}

The patients were selected upon order of appearance from the outpatient service of the Attention Deficit Hyperactivity Disorder Project in Adults (PRODATH) at the Instituto de Psiquiatria do Hospital das Clínicas da Faculdade de Medicina da Universidade de São Paulo between 2002 and 2005. The inicial re cruitement started, firstly, through the media (newspapers and magazines).

The individuals between the ages of 18 and 60 had a full psychiatric evaluation and the selected patients fulfilled the diagnostic criteria from the fourth edition of the Diagnostic and Statistical Manual of Mental Disorders (DSMIV) ${ }^{22}$ from the American Psychiatric Association for ADHD. The socio-demografic data was obtained by interviews based on Barkley's workbook ${ }^{2}$. Patients with other psychiatric disorders (e.g., organic psychoses and schizophrenia) were excluded. Those patients also participated in a molecular genetic investigation, approved by the local ethics committee. All patients received an explanation of the study, and a written informed consent was signed. 
Table 1. Distribution of marital status according to the age group in 102 adult ADHDs.

\begin{tabular}{|c|c|c|c|c|c|c|c|}
\hline \multirow[t]{2}{*}{ Marital status } & & \multicolumn{5}{|c|}{ Age group } & \multirow[t]{2}{*}{ Total } \\
\hline & & $18-25$ & $26-32$ & & $33-40$ & $>49$ & \\
\hline \multirow[t]{2}{*}{ Single } & $N^{*}$ & 26 & 7 & 10 & 6 & & 49 \\
\hline & $\%$ of total & $25.5 \%$ & $6.9 \%$ & $9.8 \%$ & $5.9 \%$ & & $48.0 \%$ \\
\hline \multirow[t]{2}{*}{ Married } & $\mathrm{N}$ & 1 & 5 & 9 & 20 & 5 & 40 \\
\hline & $\%$ of total & $1.0 \%$ & $4.9 \%$ & $8.8 \%$ & $19.6 \%$ & $4.9 \%$ & $39.2 \%$ \\
\hline \multirow[t]{2}{*}{ Divorced } & $\mathrm{N}$ & & 2 & 1 & 6 & 2 & 11 \\
\hline & $\%$ of total & & $2.0 \%$ & $1.0 \%$ & $5.9 \%$ & $2.0 \%$ & $10.8 \%$ \\
\hline \multirow[t]{2}{*}{ Widow } & $\mathrm{N}$ & & & & & 1 & 1 \\
\hline & $\%$ of total & & & & & $1.0 \%$ & $1.0 \%$ \\
\hline \multirow[t]{2}{*}{ Other way of relationship } & $\mathrm{N}$ & & & 1 & & & 1 \\
\hline & $\%$ of total & & & $1.0 \%$ & & & $1.0 \%$ \\
\hline \multirow[t]{2}{*}{ Total } & $\mathrm{N}$ & 27 & 14 & 21 & 32 & 8 & 102 \\
\hline & $\%$ of Total & $26.5 \%$ & $13.7 \%$ & $20.6 \%$ & $31.4 \%$ & $7.8 \%$ & $100.0 \%$ \\
\hline
\end{tabular}

${ }^{*} \mathrm{n}$, number of individuals.

\section{RESULTS}

A total of 102 adults diagnosed with ADHD participated in the study. The inclusion of patients was performed according to the systematic criterion (all the patients from the outpatient service were invited to take part in it).

The patients were predominantly men $(61.2 \%)$ with an average age of $33.2( \pm 9.21)$. years. They were p redominantly unmarried ( $48 \%$ ), followed by $39 \%$ of married patients, and $11 \%$ of divorcees (Table 1 ). Concerning the total years of education, $90.2 \%$ had finished high school (11 years of education) and $41.2 \%$ had obtained university degree. No differences were observed between gender and total years of education $\left(\chi^{2}=2.89\right.$, d.f.. $\left.=4, p=0.57\right)$.

From the 92 informants, 48 (52.2\%) had had to repeat their academic year at least once throughout their education. From this group of 48 patients, $20.6 \%$ (19/48) were women and $31.5 \%$ were men (no statistical differences).

At the moment of the first appointment or interview or contact, $56.9 \%$ (58/102) of them were employed, 22.5\% (23/102) were unemployed (Table 2), $14.7 \%$ studying, $4.9 \%$ working at home and $1 \%$ retired. Among the individuals who were employed, there was complaint about difficulties in their professional life like frequent job loss and poor performance at work in spite of sometimes outstanding capabilities. This has a negative impact on them and they were considered distractible and unreliable. Fortytwo patients out of 96 patients reported difficulties and distress, leading them to look for professional
Table 2. Occupation in 102 attention deficit hyperactivity dis order adult patients.

\begin{tabular}{lcc}
\hline & Number of patients & $\%$ \\
\hline Employed & 58 & 56.9 \\
Unemployed & 23 & 22.5 \\
Student & 15 & 14.7 \\
Home work & 5 & 4.9 \\
Pensioner & 1 & 1.0 \\
Total & 102 & 100.0 \\
\hline
\end{tabular}

help (psychotherapeutic and/or psychiatric appointments). Eighteen of these 42 were previously diagnosed with ADHD by other psychiatrists.

\section{DISCUSSION}

The present work is a description of the socio-demographic profile of the adult ADHD patients attending a specialized outpatient service in São Paulo, Brazil.

We observed that a majority were males (ratio 1.6:1), but it was not as dramatic as described in a child ADHD population, confirming the suggestion that symptoms in adults are equally prevalent in men and women ${ }^{23}$. However, according to Weiss and Murray ${ }^{12}$, the lack of a diff e rence between men and women may reflect a referral bias. In addition, Bieder$\operatorname{man}^{24}$ obsened that the male-female gender ratio for the ADHD in childhood is greater in clinical stud- 
ies than in community studies. This suggests that female individuals with the ADHD may be referred less $f$ requently to specialized services than male individuals, probably because ADHD is less disruptive in women then in men. However, the symptomatology is similar in both men and women during adulthood: they have poor self-discipline, short temper, difficut ties in establishing and keeping a routine or plan, and difficulties in thinking clearly ${ }^{25}$. But there are few studies re porting diff e rences between men and women with adult ADHD, where women would have more severe psychosocial impairment ${ }^{26,27}$. We can observe that the literature concerning the ADHD in adults is still limited and lacking consensus. A need of further investigation in this area is imperative.

The high educational level of the studied population, where $90.2 \%$ of the sample concluded high school, contrasts with the reality of the Brazilian population in which $39 \%$ finish high school according to IBOPE research ${ }^{28}$. A possible explanation is selection bias, although the study was carried out in a public institution, most of the patients became aware th rough the media (newspapers, magazines, Internet). This is the main methodological limitation of this report, since it is not a population based study.

In spite of the high educational level of the patients from the studied group, one of the main complaints was the difficulty of learning and the poor academic perf o rmance that can be confirmed by the re $p$ ort during their academic life, with $48 \%$ of them having failed a school year at least once. Such a finding is consistent with the literature that shows high risk of failure at school and poor academic performance in children with $A D H D^{29}$.

In this study, $11 \%$ of the patients got divorced, below the percentage presented by Biederman et al. ${ }^{14}$ who found $28 \%$ of divorces compared to the controls $(15 \%)$. However, the non- existence of a control group does not allow us to know the real difference with regards to divorce in our studied population. Also, the divorce status in a catholic country like Brazil may contribute to this difference.

The unemployment level was higher $(22.5 \%)$ in our sample compared to the Brazilian population $(12 \%)$ as observed in data from the Brazilian Institute of Geography and Statistics (IBGE) ${ }^{30}$, corroborating p revious studies that describe a poor occupational performance with frequent changes of job ${ }^{9,20}$.

Due to the age range between patients ( 20 to 56 years old), different levels of anguish and anxiety were observed, the youngest ones sought comple- tion and stability in several segments of their lives, such as in the academic life, affective relationships, work; and as for the eldest ones, who were much more woeful regarding the losses along the life, their main concern was stability in the job and family life. Many of these adults had already looked for some kind of help in the past (psychotherapy, psychiatric senice and other approaches), but without consistent results, just with the mitigation of some symptoms, but the global functioning was still impaired due to the disorganization, impulsivity and restlessness.

Until recently, adult ADHD was seldom diagnosed, mainly because of the presence of comorbidities, and the non-recognition of ADHD as a real syndrome in adults by some researchers ${ }^{13}$. ADHD starts in childhood and the physician's the first task to determine the patient's symptoms in childhood and to make a retroactive diagnosis of childhood ADHD. Although there are still controversies concerning the application of some diagnostic instruments, the clinical criteria of DSM have been widely applied in the scientific community as well as in clinical practice, for that reason it was the instrument used in this study.

The recognition of ADHD as a mental disorder is increasing significantly and the adequate diagnosis and treatment are fundamental to modify the life of these stigmatized patients.

\section{REFERENCES}

1. Mercugliano M. What is attention-deficit/hyperactivity disorder? Pediatr Clin N Am 1999;46:831-843.

2. Barkley RA. Attention-deficit hyperactivity disorder: a clinical workbook. NewYork: Guilford Press, 1998.

3. Hawi Z, Kirley A, Lowe N, Fitzgerald M, Gill M. Recent genetic advances in ADHD and diagnostic and therapeutic prospects. Expert Rev Neurotherapeutics 2003;3:453-464.

4. Wilens TE, Biederman J, Spencer TJ. Attention deficit/hyperactivity disorder across the lifespan. Ann Rev Med 2002;53:113-131.

5. Milberger S, Faraone SV, Biederman J, Testa M., Tsuang MT. New phenotype definition of attention deficit hyperactivity disorder in relatives for genetic analyses. Am J Med Genetics (Neuropsychiatric Genetics) 1996;67:369-377.

6. Andrade R, Scheuer C. Analysis of the methylphenidate's efficacy using the abbreviated version Conners' questionnaire in attention deficit hyperactivity disorder. Arq Neuropsiquiatr 2004;62:81-85.

7. F re i re ACC, Ponde MP. A pilot study of prevalence of hyperactivity and attention deficit disorder in scholar children in Salvador, Bahia, Brazil. Arq Neuropsiquiatr 2005;63:474-478.

8. Reimherr FW, Wood DR, Wender PH. An open clinical trial of L-Dopa and Carbidopa in adults with minimal brain dysfunction. Am J Psychiatry 1980;137:73-75.

9. Roy-Birne P, Scheele L, Brinkley J, et al. Adult attention-deficit hyperactivity disorder: assessment guidelines based on clinical presentation to a specialty clinic. Comprehens Psychiatry 1997;38:133-140.

10. Faraone SV, Biederman J. Neurobiology of attention-deficit hyperactivity disorder. Am J Psychiatr Neurosci 1998;144:951-958.

11. Souza I, Pinheiro MA, Mattos P. Anxiety disorders in an attentiondeficit/hyperactivity disorder clinical sample. A rq Neuropsiquiatr 2005;63:407-409. 
12. Weiss M, Murray C. Assessment and management of attention-deficit hyperactivity disorder in adults. CMAJ 2003;168:1-18.

13. McCann BS, Roy-Byrne P. Screening and diagnostic utility of self-report attention deficit hyperactivity disorder scales in adults. Comprehens Psychiatry 2004;45:175-183.

14. Biederman J, Faraone SV, Spencer T, et al. Patterns of psychiatric comorbidity, cognition, and psychosocial functioning in adults with attention deficit hyperactivity disorder. Am J Psychiatry 1993;150:1792-1798.

15. Pary R, Lewis S, Matuschka PR, Lippman S. Attention-deficit/hyperactivity disorder: an update. Southern Med J 2002;95:743-749.

16. Hesslinger B, Tebartz van Elst L, Nyberg E, et al. Psychotherapy of attention deficit hyperactivity disorder in adults: a pilot study using a structured skills training program. Eur Arch Psychiatry Clin Neurosci 2002;252:177-184.

17. Biederman J, Mick E, Faraone SV. Age-dependent decline of symptoms of attention deficit hyperactivity disorder: impact of remission definition and symptom type Am J Psychiatry 2000;157:816-818.

18. Conners CK, Jett JL. Attention deficit hyperactivity disorder (in adults and children). The latest assessment and treatment strategies. Kansas City, MO: Compact Clinicals. 1999.

19. Ram R, Schindler KM, Bauer A, Pato CN, Pato MT. The genetics of attention-deficit/hyperactivity disorder. CNS Spectrums 1999;4:49-52.

20. Faraone SV, Biederman J, Monuteaux MC, et al. Attention-deficit/hyperactivity disorder in adults: an overview. Biol Psychiatry 2000;48:9-20.
21. McGough JJ, Barkley RA. Diagnostic controversies in adult attention deficit hyperactivity disorder. Am J Psychiatry 2004;161:1948-1956.

22. American Psychiatric Association. Diagnostic and statistical manual of mental disorders, $4^{\text {th }}$ Ed. Washington, DC: Am Psychid Aseve, 1994.

23. Wender PH, Wolf LE, Wassertein J. Adults with ADHD: an overview. Adult attention deficit disorder (brain mechanisms and life outcomes). Ann NY Acad Sci 2001;931:1-16.

24. Biederman J, Faraone SV. Attention hyperactivity disorder. Lancet. 2005;366:237-428.

25. Wilens T, Dodson W. A clinical perspective of attention-deficit/hyperactivity disorder into adulthood. J Clin Psychiatry 2004;65:1301-1313.

26. Rucklidge JJ, Tannock R. Psychiatric, psychossocial, and cognitive functioning of female adolescents with ADHD. J Am Child Adolesc Psychiatry 2001;40:530-540.

27. Gaub M, Carlson CL. Gender differences in ADHD: a meta-analysis and critical review. J Am Acad Child Adolesc Psychiatry 1997;36: 1036-1045.

28. IBOPE-TARGET GROUP INDEX. Escolaridade, 2003. Available at <http:/ / www.noticias_2003_tgi_escolaridade_no.htm>

29. Biederman J, Faraone SV, Keenan K, Knee D, Tsuang MT. Family-genetic and psychosocial risk factors in DSM-III attention deficit disorder. J Am Acad Child Adolesc Psychiatry 1990;29:526-533.

30. IBGE Brazilian Institute of Geography and Statistics. Available at $<$ http/ / www.ibge.gov.br $>$ 